\title{
A literature survey of the influence of preform reheating and stretch blow molding with hot mold process parameters on the properties of PET containers Part I
}

\author{
Paweł Wawrzyniak ${ }^{1), *)}$, Waldemar Karaszewski ${ }^{2)}$ \\ DOI: dx.doi.org/10.14314/polimery.2020.5.2
}

\begin{abstract}
The paper presents a wide analysis of the literature on the modified blow molding process with simultaneous stretching of PET material for storing hot filled drinks. The hot fill process is an inexpensive conventional filling technology for high-acidity products $(\mathrm{pH}<4.5)$. It allows certain drinks (sensitive beverages such as fruit and vegetable juices, nectars, soft drinks, vitaminized water) to be stored at ambient temperature without the need for chemical preservatives. The primary feature of the bottles used in the hot fill process is their temperature stability, i.e. the ability to retain the shape of the bottle at the filling temperature. From a mechanical point of view, the thermal stability of PET [poly(ethylene terephthalate)] bottles manufactured by the ISBM (injection stretch blow molding) process is determined by the mechanical and thermal response of the blown preforms. From a microscopic point of view, the strongest influences on the mechanical and thermal properties of PET bottles are the orientation and crystallization processes. From a technological point of view, the properties of PET bottles after manufacture by the stretch blow molding process is mainly determined by the initial structure of the PET preform, the geometry and temperature distribution of the preform, the geometry of the blow mold, the temperature of the blow mold and its distribution in various parts of the mold and technological parameters of the blow molding process.
\end{abstract}

Keywords: stretch blow molding process, hot filling process, structure of PET material, hot fill PET bottles.

\section{Przegląd literatury dotyczącej wpływu parametrów procesu rozdmuchiwania $\mathrm{z}$ jednoczesnym rozciąganiem $\mathrm{z}$ zastosowaniem gorącej formy rozdmuchowej na właściwości pojemników PET \\ Cz. I.}

Streszczenie: Artykuł stanowi szeroką analizę literatury dotyczącej zmodyfikowanego procesu rozdmuchiwania z jednoczesnym rozciąganiem tworzywa PET, przeznaczonego do produkcji butelek do przechowywania napojów nalewanych na gorąco. Proces napełniania na gorąco jest relatywnie tanią konwencjonalną technologią konfekcjonowania produktów o wysokiej kwasowości $(\mathrm{pH}<4,5)$. Umożliwia przechowywanie napojów wrażliwych, takich jak: soki owocowe i warzywne, nektary, napoje bezalkoholowe, woda witaminizowana w temperaturze otoczenia bez potrzeby stosowania chemicznych środków konserwujących. Podstawową cechą opakowań stosowanych w procesie napełniania na gorąco jest ich stabilność termiczna, tj. zdolność do zachowania kształtu butelki w temperaturze napełniania. Z mechanicznego punktu widzenia stabilność termiczna butelek PET [z poli(tereftalanu etylenu)] wytwarzanych w procesie ISBM (jednostopniowa technologia wtryskiwania z rozciąganiem i rozdmuchiwaniem) jest określona przez odpowiedź mechaniczną i termiczną rozdmuchiwanych preform. Z punktu widzenia analizy mikroskopowej największy wpływ na właściwości mechaniczne i termiczne butelek PET mają procesy orientacji i krystalizacji tworzywa. Pod względem technologicznym właściwości butelek PET po wytworzeniu w procesie formowania metodą rozdmuchiwania z rozciąganiem

\footnotetext{
1) Warsaw University of Technology, Faculty of Automotive and Construction Machinery Engineering, Narbutta 84, 02-524 Warsaw, Poland.

2) Gdansk University of Technology, Faculty of Mechanical Engineering, Narutowicza 11/12, 80-233 Gdansk, Poland.

*) Author for correspondence: pawel.wawrzyniak@pw.edu.pl
} 
są determinowane głównie przez początkową strukturę preformy PET, geometrię i rozkład temperatury preformy, geometrię i rozkład temperatury formy do rozdmuchiwania oraz parametry technologiczne procesu formowania z rozdmuchiwaniem.

Słowa kluczowe: proces formowania opakowań metodą rozdmuchiwania z rozciąganiem, nalewanie napojów na gorąco, struktura opakowań PET, opakowania PET przystosowane do napełniania na gorąco.

Thermoplastics are increasingly replacing other materials in many industries due to their relatively low manufacturing costs. Poly(ethylene terephthalate), PET, was patented by John Rex Whinfield and James Tennant Dickson in 1941 [1]. A particularly noticeable trend is occurring in the packaging industry, where the number of PET containers for carbonated and non-carbonated beverages produced each year is increasing compared to other types of packaging (aluminum cans, cartons, glass containers, etc.). Rajakutty [2], citing a 2009 article, states that PET has an $8 \%$ share of the world market and that more than $90 \%$ of beverage bottles are made of PET. Recent 2014 research confirms this growing trend in the use of PET. The Plastics Europe Association of Plastic Producers [3-5] claim that demand for the use of PET in Europe is accelerating. In 2011, the demand for PET resins for packaging industry was 2.94 million tons; in 2012 it was 2.96 million tons; in 2013, 3.06 million tons; in 2014, 3.13 million tons [4]; in 2015, 3.36 million tons; and in 2016, 3.65 million tons [5]. Moreover in Europe, PET material is almost exclusively used in packaging [5]. Globally, 389 billion PET bottles were produced in 2010, 46\% of them for water packaging [6]. Cold fill PET bottles were commercially introduced to the market place for the first time in 1976 in US by Pepsi Cola, and hot fill PET bottles were introduced for the first time in 1982 in Japan by Yoshino [7].

The use of PET bottles in aseptic, hot and cold filling processes is much higher than any other packaging materials (glass, cardboard, cans, bags). The increase in PET use from 2009 to 2013 was $6.4 \%$ average annual growth rate (AAGR) and for other materials, this was only $3.6 \%$ AAGR [8]. Moreover, the food and beverage market is expected to boom in the next decade, due to the rapid growth in the world's population to 9.1 billion in 2050, which will require an increase in food production of approximately $70 \%$ [9].

According to the analysis presented by Geyer et al. [10], approximately 8300 million metric tonnes (Mt) of plastic petroleum materials (virgin plastics, i.e. polymer plus additives) were produced between 1950 and 2017. In 2015, $6300 \mathrm{Mt}$ were produced, of which 9\% were recycled, 12\% were burned, and 79\% accumulated in landfills or in the natural environment. If the current trend is maintained, this figure will be about $20000 \mathrm{Mt}$ of plastics by 2050 . Furthermore, the largest groups of total non-fibrous plastics in production are polyethylene (PE) (36\%), polypropylene (PP) (21\%), poly(vinyl chloride) (PVC) (12\%) and [poly(ethylene terephthalate)] (PET), polyurethane (PUR) ( $<10 \%$ each). Currently, $42 \%$ of all non-fibrous plastics are used as packaging, and these are mainly composed of polymers such as PE, PP and PET. However, it should be noted that polyester, mostly in the form of PET, accounts for $70 \%$ of all fibre production [10].

Due to the extensive use of polymers in packaging, they are constantly being studied and improved in terms of their mechanical, chemical and thermal strength also as materials derived from the reglanulat of PET bottles $[11,12]$.

The use of PET in packaging (e.g. foils, bottles) has stimulated the development of copolymers such as PETG (terephthalic acid copolymer with ethylene glycol and dimethoxycyclohexane). Modification of PET secondary glycol (PETG) reduces the rate of crystallization or eliminates crystalline growth, resulting in a finer crystalline structure with a high level of orientation of the amorphous phase of the bottle material, which is desirable during the manufacture of cold fill CSD (carbonated soft drinks) bottles. Since copolymer units inhibit the crystallization rate of the bottle material, preforms made from PET copolymers have not been used in the manufacture of bottles for hot filling [1].

PET bottles also have a lower impact on energy consumption and the emission of harmful chemicals into the environment compared with the manufacture of glass and aluminum containers intended for the storage of carbonated and non-carbonated foodstuffs. This evaluation is described in detail by Wawrzyniak and Karaszewski [13] based on an analysis of data in the literature. This analysis shows that PET bottles consume the least energy in the manufacturing process, while aluminum cans are least likely to be produced. The assessment of the impact of emissions from harmful substances is not unequivocal, given the various chemicals that are emitted during the process of manufacturing individual packages. However, it can be concluded that PET bottles are the most environmentally friendly containers for the most commonly cited compounds (carbon dioxide, sulphur dioxide, nitrogen oxides).

It is worth noting that intensive research is currently ongoing into the use of PET as a mixture with other polymers or nanofillers [14], produced from biomass other than petroleum or reclaimed via material recycling $[15,16]$, which is known as 'super clean' recycling [17]. However, due to the decrease in the weight of packaging relative to the constant weight of closures and labels, the recycling of PET packaging is becoming less economically profitable every year [18]. These aspects are not discussed further in this paper. 
The stability of the stored beverage depends largely on the development of microorganisms in the beverage and its oxidation by oxygen during storage. Standard PET material provides an effective barrier to oxygen (the permeability to oxygen of commercially available $600 \mathrm{~cm}^{3}$ PET bottles at $4^{\circ} \mathrm{C}$ and relative humidity $50 \%$ is $0.02 \mathrm{~cm}^{3} /$ day [18]), which, depending on the product being filled, allows for a shelf life of six to 12 months at ambient temperature for most high-acid beverages stored in $1 \mathrm{~L}$ bottles [8]. For longer storage or for packages smaller than $1 \mathrm{dm}^{3}$, active oxygen acceptors can be added to the PET material during the preform injection step.

Many studies indicate that pasteurization during hot filling results in the thermal inactivation of Alicyclobacillus acidoterrestris (AAT) bacteria in fruit juices. AAT, sometimes called Bacillus acidocaldarius (BAM), are non-pathogenic bacteria found in several commercially pasteurized fruit juices. It has been proven that the pasteurization of acidic fruit juices $(\mathrm{pH} 4.6)$ at $85-95^{\circ} \mathrm{C}$ inactivates any microorganisms that are capable of spoiling the product [19]. These bacteria may have a slow growth cycle (up to five days) and are responsible for the unpleasant taste of spoiled fruit, although these substances are not hazardous to human health [19]. However, it should be noted that some studies have shown that pasteurization at low temperatures of frozen high-acid orange juice $(\mathrm{pH} 3.8$ and $\left.66.17^{\circ} \mathrm{Brix}\right)$, filling at $85^{\circ} \mathrm{C}$ and sudden cooling of the bottle with cold water did not prevent bacterial survival and further growth after five to six days of storage at $35^{\circ} \mathrm{C}$ [20].

In order to destroy microorganisms, sterilization is administered to the beverage by a pasteurization process, and the bottles are then filled with the beverage. All beverages kept at room temperature are filled in three ways [8]:

- Hot fill process: filling of the beverage takes place during the pasteurization process of a beverage that has been preheated from $85^{\circ} \mathrm{C}$ to $92^{\circ} \mathrm{C}$ [8]; however, other temperatures can be found in many publications, such as $81-95^{\circ} \mathrm{C}$ [7], $78-93^{\circ} \mathrm{C}$ [21], and up to $97^{\circ} \mathrm{C}$ [1]. The heated beverage also sterilizes all the inside surfaces of the bottle and cap. The hot fill process therefore requires special hot fill bottles with high thermal stability in order to withstand the high filling temperature.

- Aseptic fill process: aseptic pouring is complex and capital intensive. This process involves controlling many aseptic joints using complex technologies, eventually introducing sterilization requirements. Aseptic pouring requires the disinfection of the preform or bottle and cap via chemical and sterile rinsing. A drink that has undergone the pasteurization process is then poured at ambient temperature under strict aseptic conditions. The aseptic fill process therefore requires common cold fill bottles with low thermal stability.

- Cold fill process: this is the cheapest method of filling pasteurized beverages at room temperature under normal conditions. It requires the addition of preservative chemicals to the beverage during the cold filling pro- cess (at room temperature); however, this is currently less acceptable to consumers [8].

Bottles for aseptic and cold filling are produced in identical stretch blow molding (SBM) processes, while bottles for hot filling are produced in a modified SBM process with an additional annealing step in hot blow mold.

The aseptic filling of beverages into PET bottles from life cycle assessment (LCA) is a more environmentally safe way of filling beverages (many factors are taken into account here, including climate change, ozone depletion, terrestrial acidification, freshwater eutrophication, marine eutrophication, human toxicity, photochemical oxidant formation, particulate matter formation, terrestrial ecotoxicity, freshwater ecotoxicity, marine ecotoxicity, ionising radiation, water depletion, metal depletion, fossil depletion) compared to hot filling, in terms of the materials, energy inputs and emissions to the environment of secondary products. This is mainly due to the greater weight of the bottles used in the hot filling process [9]. However, according to a Plastipak brochure [8], aseptic filling is economically justified for the production of more than 50 million bottles a year, as it requires very high cost of keeping standards of cleanliness. It is much simpler to implement (using standard cold fill PET bottles), since standard PET bottles are thermally stable at filling temperatures of up to $60^{\circ} \mathrm{C}$ [22]. Although hot filling requires specially prepared bottles, the production cost is lower. The manufacture of a thermally stable bottle will be discussed in greater detail in the following chapters. The sterilization of hot beverages creates particular problems for traditional cold PET bottles, as they shrink and distort at temperatures above $60^{\circ} \mathrm{C}$.

The current commercial processes for thermally stable bottles make it possible to use hot filling temperatures of up to $97^{\circ} \mathrm{C}$ [1]. It is necessary to raise the thermal resistance of packaging to enable it to withstand the autoclave process (involving the pasteurization of filled packages for 45 minutes at $121^{\circ} \mathrm{C}$ [7]). PET bottles for hot fill must be resistant to the following loads during hot filling [21]:

- Temperature increase during filling, which can cause shrinking of the bottle due to the relaxation processes in the uncrystallized phase; residual stresses are ultimately responsible for deformation of a product on reheating above the glass transition temperature, such as shrinkage or warpage in hot filled bottles [7].

- Pressure on the bottle thread as it is warmed by the beverage, which can deform the thread of the bottle and decrease the airtightness.

- Creation of a vacuum in the bottle as a result of the cooling of the liquid in the closed bottle, which can deform the body and base of the bottle.

In order for PET bottles to withstand elevated hot fill temperatures, they must be made in such a way that there is no permanent deformation of the bottle when they are filled with hot beverages [21]. The basic requirements for hot fill bottles are that:

- The container can compensate for the deformation of the vacuum pressure by its shape, or a pressure has to 
be introduced that compensates for the vacuum pressure from the contraction of the beverage.

- The volume of the container does not shrink by more than $2 \%$ after the hot drink has been filled.

- The thread is not deformed, which means that the lid can be closed tightly.

The above requirements can be met through the use of two technologies for the production of hot fill preforms and two technologies for the production of hot fill bottles. Preform production technologies involve the production of preforms with a thicker wall in the vicinity of the thread or with a crystallized thread. Bottle production technologies involve the production of panel or panel-less bottles.

\section{ORIENTATION AND CRYSTALLIZATION PROCESS IN SBM FROM PREFORM TECHNOLOGY}

The injection stretch blow molding (ISBM) process is the most commonly used method of producing PET containers for cold filled beverages [23-25], since it improves the mechanical properties of the container material by introducing a biaxial orientation in the amorphous phase and increasing the crystallinity of the material, while retaining a fine-grained structure. Many polymers, including PET, exhibit greater mechanical strength along the orientation of the macromolecular chains, and their thermal and mechanical resistance increases with increased crystallinity, although a direct correlation is not seen (direct mechanical and thermal resistance is associated with relaxation in the amorphous phase). In the case of beverage containers manufactured from this material, the degree of crystallinity generally does not exceed $40 \%$, and according to Boyd [1], the degree of crystallinity of the bottle sidewalls must not exceed 37\%; this is because the transparency of the material and the barrier it presents to gases deteriorate. It can be shown that the highest strength and barrier properties for the cold filling bottles are obtained from the ISBM process [26].

The final bottle structure affects its quality, i.e. its mechanical, aesthetic and thermal properties. In the ISBM process, the number of parameters that can affect the bottle quality is very high, involving about 14 variables [27]. The most important of these are the geometry of the blow mold, the geometry of the preform, the preblow and final blow air pressure, the speed of the stretching rod, the preform temperature distribution and the delay of the preblow valve opening time, in terms of the position of the stretching rod (referred to here as "delay") [27-29]. For hot fill bottles, due to the annealing process, there are several additional parameters: the time of annealing, temperature profile of the hot mold, the temperature of the cooling air and the delay of the air cooling valve opening during annealing.

Issues related to the influence of SBM process parameters on the properties of cold fill PET bottles have been discussed in many articles [28-34]. However, the influence of SBM process parameters on the properties of hot fill PET bottles has been described in a much smaller number of works, the most important of which is by Boyd [1]. This work shows that crystallinity is not an absolute indicator of mechanical strength, thermal stability and barrier ability, but is more strongly related to a relaxation of the amorphous PET phase. Moreover, above a certain level, the greater the crystallinity of the material, the lower the barrier properties of the material, an effect that is related to the so-called free volume [1].

If the deformation occurs at a temperature that is no lower than the glass transition temperature, crystallization is observed simultaneously with the orientation of the chains. This is true as long as the deformation speed is not too high, and only after exceeding the SHP (strainhardening parameter, or natural draw ratio) parameter required for crystallization nuclei, i.e. triangular structures. It should be noted that the mer structure is a major factor in determining where the glass transition temperature occurs; a material with a similar structure but without the benzene ring has a glass transition temperature that is $140^{\circ} \mathrm{C}$ lower than that of PET [7]. Above a deformation speed of approximately $1 / \mathrm{s}$, the crystallization process takes place only after the deformation process is complete, although the process of chain orientation and the formation of nematic and smectic mesophases occur both during and after deformation, irrespective of the deformation speed. The crystallization process takes place around stable crystallization nuclei, e.g. around stable triangular structures (if no crystallization has occurred during deformation, a greater number of areas may have triangular-oriented structures). Therefore, if the rapid deformation process is followed by very rapid cooling to below the glass transition temperature, a very large orientation and a high degree of crystallinity (about 20-25\% [7] or more [24]) is obtained, with small crystallites since there are many crystallization nuclei. This material will be characterized by a very high mechanical strength and barrier but also a relatively low thermal stability, since a higher thermal stability is achieved for completely different microstructure of the material, giving rise to dimensional stability due to the effects of increased temperature. Moreover, the strain that leads to orientation is associated with the generation of residual stresses in the container wall [7].

For maximum thermal stability, the microstructure should contain the minimum proportion of nematic and smectic mesophases (i.e. the least-oriented amorphous phase) and a high degree of crystallinity, with large, perfect crystallites. In order to obtain a small number of large crystallites, there must be few crystallization nuclei, and this can be achieved via slow deformation at a temperature that is much higher than the glass transition temperature. However, in the SBM process, the deformation speed is very high, and in order to obtain a small number of mesophase and large crystallites after the 
rapid deformation in the SBM process, the material must be kept for a certain time at or around the crystallization temperature (for annealing). For clean PET material, the minimum half time crystallization induced by temperature from an initially amorphous material, or consequently the maximum crystallization rate induced by temperature, is achieved within a temperature range of $170-190^{\circ} \mathrm{C}$ [7] with a crystallization time on the order of seconds. Although the rate of crystallization slows down with increases in the molecular weight, co-monomer content and type, residual catalysts, and diethylene glycol (DEG), which is formed during the manufacturing of PET, the shape of the half time crystallization rate $v$. temperature curve remains very similar [7]. It is worth emphasising that numerical simulations of rubber state models with nematic microstructure show that during uniaxial deformation of such material, there is a simultaneous transverse contraction of the sample that is smaller than the contraction of the microstructure induced by the orientation of the particles in the nematic order [35]. This may be due to the fact that microcavity effects occur during the deformation of the material, and that these are associated with the phenomenon of orientation of the microstructure. The intensification of the cavitation process in the purified polypropylene samples can be explained by changes in the amorphous phase, i.e. the changes in free volume arising from the elimination of low fractions and soluble additives. An increase in free volume was probed with positron annihilation lifetime spectroscopy. The intense formation of cavitation pores in purified polypropylene proves that the initiation of cavitation in polypropylene has a homogeneous nature (the homogeneous nucleation of cavitation), as shown by Rozanski et al. [36]. These authors predict similar behavior in other crystalline cavitating polymers, and associate this with the extraction of additives and the low molecular weight fraction.

Post-thermal annealing, at temperatures significantly above the polymer glass transition but below the melt temperature, is an approach to accelerating polymer chain relaxation and altering molecular organization, and realizing improvements in the bulk properties, as shown by Fei et al. [37]. These authors also present a very good summary of the influence of annealing on the microstructure properties of a polymer material. It has also been found that annealing can be used to reorganize amorphous material or less-perfect crystals into larger or more perfect crystalline structures [38-40], to relieve internal stresses [41], to promote phase separation of multi-phased material [40], and to alter the mechanical [39-42], optical [43], barrier [44] and dielectric [45] properties and the conductivity [46-48] of polymer materials.

During the annealing process, after crystallization is induced by deformation in the SBM process, secondary crystallization processes are induced by temperature that result in an increase in the size of the crystallites. At the same time, they become more perfect, i.e. vari- ous defects in the crystalline lattice disappear and small crystalline structures merge into larger agglomerations of crystalline structures. However, the amount of amorphous phase surrounding the growing crystallite and within large crystalline agglomerations in inter-lamellar areas decreases, meaning that large crystalline agglomerations becomes more perfect [49]. In addition, dipping unstretched PET for 30 minutes in acetaldehyde causes:

- A reduction in the trans conformation of two carbonyl groups adjacent to the benzene ring.

- An increase in the number of ordered lamellar crystals (an increase in the trans conformation of the glycol group).

- An increase in the perpendicular position of the carbonyl group and the benzene ring relative to each other.

- An decrease in the density in a direction perpendicular to the plane, which may cause a reduction in the structural packing of PET chains.

A similar phenomenon may occur in non-pure PET samples. The used additive can cause similar changes in the conformation and dilution of the system, and hence a reduction in the density of the material. However, this conclusion remains to be verified in experiments using the SBM process.

Crystallites that contain the amorphous phase are less thermally stable than crystallites that do not (Ishinabe, 2017), but the growth of crystallites at the expense of the surrounding amorphous phase causes an increase in the free volume in the surrounding amorphous phase. As a result, the mechanical and barrier properties of PET material are reduced, meaning that hot fill PET bottles are not suitable for storing carbonated drinks. However, if an increase in crystallite perfection can be obtained without increasing the free volume of the surrounding amorphous phase, then the mechanical and barrier properties of the bottle can be increased. This can be achieved via a technology called double blow molding patented in 1996 [50-52]. The enhancement of the barrier compensates for the effects of reduced wall thickness in lighter weight packaging. In an SBM process with typical heat settings, the level of crystallinity reached is $30-35 \%$, while for the double blow process, this figure can be $40 \%$ or higher [7].

Cold and hot fill bottles for various purposes require different microstructures of the bottle material. For cold fill bottles, the highest deformation rates are therefore used in conjunction with the highest deformation ratios, the lowest deformation temperatures (i.e. the lowest possible preheating temperatures at which no micro-cracking occurs, which results in a "stress" whitening of the material) and the fastest cooling speeds of the formed bottle below the glass transition temperature, so that the resulting structure contains as much as possible of the oriented amorphous phase (nematic and smectite meshes) and has a fine-grained crystal structure. It should be noted that the higher deformation rates for low temperatures (due to the low mobility of micromolecules and therefore the high viscosity of the material) gener- 
ate a higher energy dissipation in the material (which is very random phenomenon), and this leads to a self-heating effect. Research conducted by Luo and Chevalier [53] found that the self-increase in the temperature of a free blown PET preform can reach almost $18^{\circ} \mathrm{C}$, which can counteract the formation of mesomorphic amorphous structures. Furthermore, the strong influence of temperature on the behavior of the polymer is well known, and $\mathrm{a} 10^{\circ} \mathrm{C}$ increase can lead to a tenfold reduction in the viscosity, making it more difficult to control the material distribution in the thickness of the bottle wall during blowing from preform. The most recent studies on the blowing kinetics of the preform in free blow have been described in an article by Yan et al. [54]. It was found that in this blowing scenario, the change in the stress-strain curve gradient in the strain hardening region in tests at different heating temperatures was lower than that in biaxial stretching tests, due to a combination of effects from the temperature and strain rate.

A different situation exists for hot fill bottles. Relatively high deformation ratios are required, with low deformation rates (although these are not suitable as they reduce the machine's performance), high deformation temperatures (since at highest possible temperatures for heating preforms, no crystalline structures appear that can break down the sun's rays to manifest as "thermal" whitening of material) and the slowest cooling speeds of the molded bottle below the glass transition temperature. In addition, the SBM process for hot filling bottles is complemented by an annealing process of the formed bottles, so that the resulting structure contains as little as possible of the oriented amorphous phase (nematic and smectic mesophases) and coarse-grained crystal structure.

Hence, there is a conflict between achieving high thermal strength, and high mechanical strength and barriers. In order to minimise this conflict in the production of hot filling bottles, PET material is used that has a higher intrinsic viscosity $\left(I V=0.080-0.086 \mathrm{dm}^{3} / \mathrm{g}\right)$ than that used in the production of cold filling bottles $\left(I V=0.078-0.082 \mathrm{dm}^{3} / \mathrm{g}\right)$. At higher material viscosities, the processes of orientation of the amorphous phase are hindered by the greater entanglement between long chains, and this translates into the increased barrier properties of the amorphous phase. A reduction in the amount of oriented amorphous phase in a material with a higher intrinsic viscosity does not cause the same degree of barrier loss as the same reduction of the oriented amorphous phase in a less viscous material.

It has been shown that PET material has a dynamic microstructure network during the SBM process. Although classical theories of rheology and mechanics have enabled us to characterise these materials, there is still a gap in our understanding in terms of how individual components (i.e. the mechanics of each building block and its connection with others) affect the emerging response of the network. Attempts have been made to model the topological network changes of materials with dynamic networks using the kinetic theory based on statistical mechanics; however, this has only been done for uniaxial stretching with a strain rate of up to $1 / \mathrm{s}$ [55], while the average deformation speed of material in the SBM process has been found to be 50/s [56].

\section{FORMING PROCESS OF HOT FILL PET BOTTLES}

The complete hot filling process involves the production of the appropriate PET granulate, formation of the preform in the injection molding process, formation of a hot filling container, pasteurization and pouring of the beverage, bottle closure and cooling of the beverage within the closed bottle.

Major manufacturers of PET material for the hot fill process include Indorama, Clariant, M\&G Polimeri Italia SpA, NEO Group, Novapet S.A., Reliance Industries Ltd, DAK Americas LLC, La Seda de Barcelona S.A., and the Eastman Chemical Company. The primary manufacturers of blow molding machines for the production of hot fill bottles include Krones Ag, KHS Corpoplast, S.I.P.A. S.p.A, Sidel, the Nissei ASB Machine Co. of Japan, W. Amsler Equipment Inc., TECH-Long Packaging Machinery Co. Ltd, and TES Sp. z o.o.

Figure 1 shows all phases of hot filling of beverages into PET bottles with the exception of (1) granulate production, including (2) granulate drying and crumbling, (4) forming preforms with crystalline thread or (5) standard thread but with enlarged thickness on (3) the injection machine, the formation of (8) the panel bottle or (9) the panel-less bottle on the stretch blow molding machine (6 or 7 depending on the annealing process), (10) pasteurisation, (11) filling, (13) capping, (14) inverting to sterilise the bottle neck and thread, (15) cooling, (17) labelling and (18) bottle packaging. This paper will describe the process of forming panel-less hot fill bottles without a crystallised thread. In industry, two methods have been developed to neutralise the deformation of the filled and sealed bottle after cooling: the nitrofill (12) and thermoshape processes (16).

Preforms are manufactured by an injection molding process from low-crystallization PET standard granulate, but with a higher viscosity relative to the PET used for cold filled bottles. The recommended moisture content of the PET material to prevent viscosity degradation (as a result of hydrolysis) of PET during the manufacture of hot filling containers should be less than $0.010 \%$ (100 ppm). Nevertheless, most PET users recommend a maximum moisture content of the raw material not exceeding $0.005 \%$ (50 ppm). Even granulate shredding has an impact on the quality of the bottle (along with the increase in granule disintegration, most mechanical properties are improved [57]). The shape and geometry of the preform is critical for producing a container with good transparency and physical properties.

In the process of hot filling, the juices are initially heated in a continuous heat exchanger, which is typically a tube- 


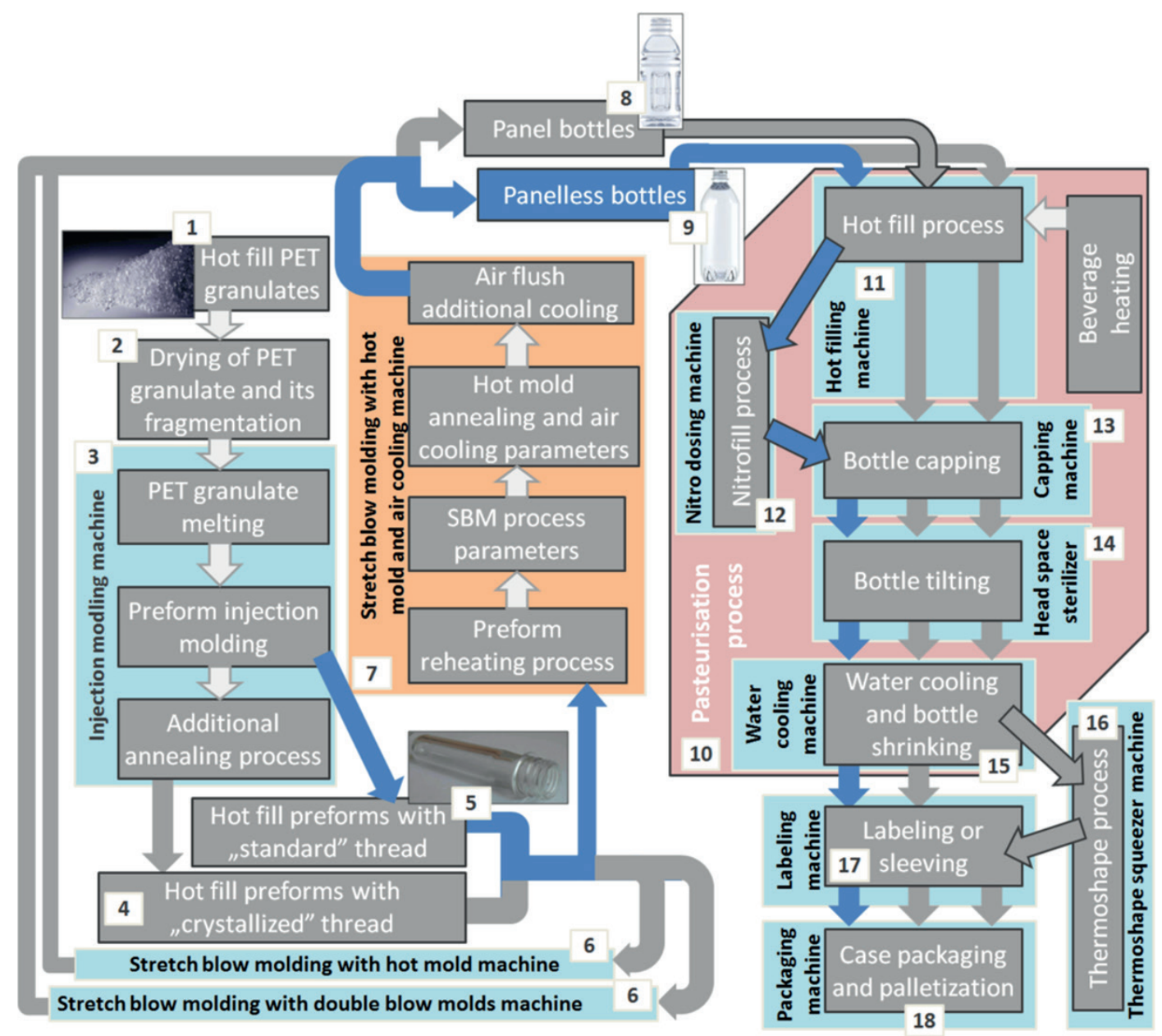

Fig. 1. All phases in the process of filling hot beverages into PET bottles, i.e. production of the preform and bottle, pasteurization, pouring, closing, reversing to sterilize the bottle thread, cooling, labelling and packaging of panel bottles (the meaning of the numbers is explained in the text)

type or plate exchanger [9], to pasteurization temperatures (normally between $92^{\circ} \mathrm{C}$ and $105^{\circ} \mathrm{C}$ ) and are kept at these temperatures for 15-30 seconds (although orange juice is pasteurized at $95^{\circ} \mathrm{C}$ for $15 \mathrm{~s}$ ). They are then sent to the filling tank in filling machines, where the juice temperature is reduced to the filling temperature (the hot filling temperature must be at least $82^{\circ} \mathrm{C}$, and cannot exceed $90-92^{\circ} \mathrm{C}$ due to the limited thermal strength of PET containers without a crystallised thread [8]). From the tanks, the beverage is then taken up by the filler and filled into PET bottles, where it is kept for about 30-120 seconds at a high temperature, during which time the bottle is closed and tilted upside down, thereby sterilizing all the inner surfaces of the bottles. If the filling device is stopped during the process, the beverage in the tank is recycled and reheated in the pasteurizer to maintain a temperature within the range of $88-92^{\circ} \mathrm{C}$. The maximum recirculation of the product in the machine is $10 \%$ [9].

When the containers have been filled, they are closed and then often tilted for up to about 15 seconds to ensure contact between the product and the top surfaces of the container. The hot liquid heats the neck, which softens, and due to the action of the force from the closure, may deform and cause leakage between the bottle and the cap. Slightly thicker necks and threads that are still made of standard amorphous (i.e. transparent) PET are usually sufficient to prevent neck deformation up to approximately $92^{\circ} \mathrm{C}$, but not at the highest temperatures of hot filling. For very high filling temperatures, experience shows that special heat treatment is required for the bottle necks, using a metal closure (aluminum or steel) to prevent deformation and leakage. With these metal closures, bottles are usually used that have crystallized threaded parts of the neck [22]. For amorphous threads intended for hot filling, the bottles are sealed with one- or two-piece standard lids.

The containers are then transported to the tunnel, where they are first kept at the filling temperature for one to two minutes to ensure "commercial sterility", and then cooled rapidly with cold water supplied from the chiller. Rapid cooling of the product prevents the sugar from boiling and subsequently changing the colour of the product and prevents the vitamin content from being degraded due to prolonged exposure to elevated temperatures $[8,9]$.

Water spray cooling is a better way to cool bottles than bath or air cooling. Air cooling is extremely slow (with 
a heat transfer coefficient of $U_{s} \sim 10 \mathrm{~W} / \mathrm{m}^{2} \mathrm{~K}$ ) but can be increased by a factor of 1.5 in dynamic (rotating) conditions. Water cooling is more than an order of magnitude faster, and differences between water bath and spray cooling have been found to be noticeable but not very significant (between $6 \%$ and $23 \%$ ). A vertical bottle position for cooling has been shown to be invariably slower than a horizontal one [58]. Dynamic cooling tests show that rotation at $200 \mathrm{rpm}$ can increase the heat transfer coefficient by about $230 \%$. As expected, the PET wall thickness has been shown to affect heat transfer coefficient increasingly with the $U_{g}$ value. Furthermore, it is notable that in static water cooling, a difference in the heat transfer through the PET layer leads to different fluid dynamic conditions, both inside and outside the bottle. When bottle undergoes rotation, meaning that the system undergoes forced convection, this phenomenon loses importance. Overall, the best approach is dynamic cooling under water spray, since this allows for cooling with a characteristic time $\tau$ of about $150 \mathrm{~s}$, which is compatible with typical cooling times after the pasteurization process. As the heat transfer is mainly limited by the internal heat transfer coefficient, different ways to promote internal mixing (e.g. shaking, rotation around different axes) should be explored in order to further reduce the cooling time [58].

The traditional technology used for beverage preservation is thermal pasteurization, which can be broadly classified into low-temperature/long-time (LTLT) and hightemperature/short-time (HTST) processes, the application of which depends on the food substrate to be processed [59]. LTLT is typically adopted for milk and dairy products $\left(63^{\circ} \mathrm{C}\right.$ for at least $\left.30 \mathrm{~min}\right)[60]$, while HTST pasteurization is more suitable for fruit juices [61], where temperatures from $72^{\circ} \mathrm{C}$ to $108^{\circ} \mathrm{C}$ are employed with holding times (HTs) of at least $15 \mathrm{~s}$. The aim of thermal pasteurization is to kill pathogens and substantially reduce the number of spoilage microorganisms through a suitable combination of time and temperature. The major drawback of both of these methods is the degradation of taste, colour, flavor and nutritional quality of foods [62]. Moreover, beverages that are bottled after thermal treatments also require expensive aseptic filling systems to prevent the risk of post-processing contamination. For these reasons, various novel pasteurization technologies have been developed in recent years, including thermal and non-thermal methods [62]. Recently, a new thermal treatment to inactivate microorganisms in beverages has been patented [63] in which the basic idea is a radiofrequency $(\mathrm{RF})$ heating process with temperature rates higher than $28^{\circ} \mathrm{C} / \mathrm{s}$ and final temperatures up to $65^{\circ} \mathrm{C}$, in combination with a pulsed electric field. According to these authors, the lethal effect on microorganisms arises from the irreversible formation of pores in the lipid cell coatings, due to the rapid temperature increase.

Cammalleri et al. [59] presented the first experimental results obtained from the application of this new ther- mal treatment, with different combinations of the processing parameters (rate of temperature rise, final temperature and holding time), on separate suspensions of Pseudomonas aeruginosa, Escherichia coli, Staphylococcus aureus, Listeria innocua and Candida albicans. As an overall outcome, the new thermal process was shown to effectively reduce the microbial load of all tested strains. Due to the short duration of the treatment and the relatively low maximum temperature $\left(65^{\circ} \mathrm{C}\right)$, which does not damage the plastic materials commonly used in the beverage industry for bottles and packaging, the treatment is compatible with previously packaged products.

After hot filling, cooling of the product is associated with deformation of the entire bottle (collapsing) resulting from the vacuum inside the bottle after the beverage, the bottle, the gas and the vapor beverage trapped in the bottle have cooled down (unless the beverage has been applied to the edge of the bottle thread). This is because liquids and gases expand on heating, and their volume is reduced again when they cool (the vapor beverage also change their phase state from gas to liquid). For example, after cooling from a filling temperature of $87^{\circ} \mathrm{C}$ to room temperature, the volume of orange juice shrinks by about $3 \%$ [64]. In the case of a glass bottle, this is not a problem, but in the case of a PET bottle, its shape will be deformed.

Filling the bottle to the very top of the neck minimizes the reduction in internal pressure (minimizes negative pressure by eliminating gases), although it cannot be eliminated completely due to the reduced volume of the beverage itself, and this also involves the risk of the beverage pouring out when the bottle is opened. In addition, filling the bottle to the very top of the thread introduces the problem of ensuring that each bottle stores the beverage volume stated on the label of the bottle [20]. In addition to the shrinkage of the bottle during filling, it was also found that PET bottles may shrink slightly during storage at room temperature before filling, since the shrinkage volume is higher, for a higher storing temperature, for instance in the summer. Precise control of the bottle production process to minimize the residual stress created in the bottle during blowing is essential to ensure the required volume of the bottle, especially in summer when the storage temperatures are the highest.

This problem can be worked around by designing a bottle that can be filled while leaving some free volume. An older solution is the use of panel bottles, which consist of rigid bottle-shaped parts and flexible vacuum panels; these suppress the vacuum by elastic deformation without apparently changing the shape of the bottle. However, this type of bottle is difficult to produce and is unappealing to consumers; they are difficult to label and therefore most often use the technology of the shrinking sleeve (as a form of label) as the traditional type of label may be wrinkled. Shrink sleeves are four times as expensive as paper labels [64] and much heavier. In addition, the weight of these bottles is much higher than that of panel-less hot fill bottles. 
The internal vacuum conditions resulting from the cooling of the gas and beverage enclosed in the bottle can also be compensated for using panel-less bottles, although this technology requires an additional step. Compared to standard hot fill panel bottles, panel-less technology saves more than $16 \%$ of the bottle weight for the same volume of beverage, by reducing the need for PET material for a complicated panel design. This reduces the cost of both the bottles and labelling [65]. Two technologies have been developed to allow the use of panel-less PET bottles in the hot filling process: the NitroFill process and the Thermoshape ${ }^{\mathrm{TM}}$ process.

The Thermoshape ${ }^{\mathrm{TM}}$ process was developed by Plastipak and is based on the fact that after filling the bottle with the beverage (to less than the total volume of the bottle), closing and cooling the free space results in a vacuum that deforms the shape of the bottle. The bottom of the bottle is then heated, and the bottle is squeezed from underneath, thereby increasing the pressure on the bottle. In this way, the lateral shape of the bottle is reduced to its original shape. At the same time, this results in a slight overpressure inside the bottle, which increases the mechanical strength of the closed package.

The NitroHotfill process was developed by Krones [66]. This process eliminates the issue of free space after filling the hot beverage, for any shape or volume of container. The NitroHotfill process involves four steps:

- hot filling;

- dispensing of liquid nitrogen (drop);

- closure and sterilizing of internal bottle surfaces using tilting and the evaporation of nitrogen, which causes a pressure rise in the bottle (up to approx. $1.8 \cdot 10^{5}$ Pa manometric pressure);

- cooling so that the pressure drops and nitrogen gas maintains a slight overpressure (up to about $0.410^{5} \mathrm{~Pa}$ of manometer pressure) in the bottle, so that the bottle is able to withstand a greater external load.

The hot fill process was also implemented by other companies like NISSEI ASB [67] and SIPA [68].

\section{REFERENCES}

[1] Boyd T.J.: "Transient crystallization of poly(ethylene terephthalate) bottles", The University of Toledo, 2004 Toledo.

[2] Rajakutty A.: "Static and dynamic mechanical properties of amorphous recycled PET", Anna University, 2010 India.

[3] Plastics-Facts 2014, PlasticsEurope Association of Plastic Producers: "Analysis of production, demand and recovery of plastics in Europe", PlasticsEurope, 2014.

http://www.plasticseurope.org/documents/ document/20150127125822-tworzywa-fakty_2014_ final.pdf/ (accessed 1 January 2018).

[4] Plastics-Facts 2015, PlasticsEurope Association of Plastic Producers: "An analysis of European plastics production, demand and waste data", PlasticsEurope, 2015. https://www.plasticseurope.org/application/files/371 5/1689/8308/2015plastics_the_facts_14122015.pdf.

[5] Plastics-Facts 2017, PlasticsEurope Association of Plastic Producers: "An analysis of European plastics production, demand and waste data", PlasticsEurope, 2017.

https://www.plasticseurope.org/application/ files/5715/1717/4180/Plastics_the_facts_2017_FINAL_ for_website_one_page.pdf/ (accessed 1 January 2018).

[6] Orset C., Barret N., Lemaire A.: Waste Management 2017, 61, 13.

https://doi.org/10.1016/j.wasman.2016.12.034

[7] Weissmann D.: "Applied Plastics Engineering Handbook: Processing and Materials" (Ed. Kutz M.), William Andrew, pp. 603-623.

https://doi.org/10.1016/B978-0-323-39040-8.00034-1

[8] Plastipak brochure 2011. https://pl.scribd.com/document/186284208/2011ThermoShape-Brochure-Web/(accessed 1 January 2018).

[9] Manfredi M., Vignali G.: Journal of Food Engineering. 2015, 147, 39. https://doi.org/10.1016/j.jfoodeng.2014.09.018

[10] Geyer R., Jambeck J.R., Law K.L.: Science Advances $2017,3,1$.

https://doi.org/10.1126/sciadv.1700782

[11] Ronkay F., Molnar B., Szlay F. et al.: Polymers 2019, 11 (2), 233. https://doi.org/10.3390/polym11020233

[12] Vo P.P., Doan H.N., Kinashi K.: Polymers 2018, 10 (6), 680.

https://doi.org/10.3390/polym10060680

[13] Wawrzyniak P., Karaszewski W.: Opakowanie 2013, 4, 50.

[14] Shen Y., Harkin-Jones E., Hornsby P. et al:: Composites Science and Technology 2011, 71, 758.

https://doi.org/10.1016/j.compscitech.2011.01.024

[15] Wawrzyniak P.: Opakowanie 2014, 4, 69.

[16] Awaja F., Pavel D.: European Polymer Journal 2005, 41, 2614.

https://doi.org/10.1016/j.eurpolymj.2005.05.036

[17] Welle F.: Conservation and Recycling 2011, 55, 865. https://doi.org/10.1016/j.resconrec.2011.04.009

[18] Kontominas M.G.: "Food Packaging and Shelf Life" (Ed. Robertson G.L.), Taylor and Francis Group, LLC, 2010, pp. 81-102.

[19] Groenewald W.H., Gouws P.A., Witthuhn R.C.: African Journal of Microbiology 2013, 7, 2736. https://doi.org/10.5897/AJMR12.1789

[20] Spinelli A.C., Sant'Ana A.S., Pacheco-Sanchez C.P., Massaguer P.R.: International Journal of Food Microbiology 2010, 137, 295. https://doi.org/10.1016/j.ijfoodmicro.2009.11.003

[21] Krones brochure 2015. http://www.unitedfoodandbeverage.com/wp-content/uploads/2015/10/contiform_en.pdf/ (accessed 1 January 2018). 
[22] Giles G.A., Bain D.R.: “Technology of Plastics Packaging for the Consumer Market", WileyBlackwell 2001.

[23] Cho Y.J., Ryu K.Y., Lee S.W.: “Computational Science and Its Applications - ICCSA 2007. Lecture Notes in Computer Science" (Eds. Gervasi O., Gavrilova M.L.), Springer, Berlin, Heidelberg 2007, 4707, 11. https://doi.org/10.1007/978-3-540-74484-9_2

[24] Wawrzyniak P., Datta J.: Przemyst Chemiczny 2015, 94, 1114. https://doi.org/10.15199/62.2015.7.17

[25] Wawrzyniak P., Datta J.: Przemyst Chemiczny 2015, 94, 1110. https://doi.org/10.15199/62.2015.7.7

[26] Strong A.: "Plastics, Materials \& Processing", Prentice Hall, Inc. 2006.

[27] Wawrzyniak P., Karaszewski W.: Journal of Applied Computer Science 2014, 22, 101.

[28] Salomeia Y.M., Menary G.H., Armstrong C.G.: Advances in Polymer Technology 2013, 32, E771. https://doi.org/10.1002/adv.21320

[29] Salomeia Y.M., Menary G.H., Armstrong C.G.: Advances in Polymer Technology 2013, 32, E434. https://doi.org/10.1002/adv.21291

[30] Schmidt F.M., Agassant J.F., Bellet M.: Polymer Engineering and Science 1998, 38, 1399. https://doi.org/10.1002/pen.10310

[31] Adams A.M., Buckley C.P., Jones D.P.: Polymer 2000, 41, 771. https://doi.org/10.1016/S0032-3861(98)00834-9

[32] Menary G.H., Tan C.W., Armstrong C.G. et al.: Polymer Engineering and Science 2010, 50, 1047. https://doi.org/10.1002/pen.21555

[33] Menary G.H., Tan C.W., Harkin-Jones E.M.A. et al.: Polymer Engineering and Science 2012, 52, 671. https://doi.org/10.1002/pen.22134

[34] Bordival M., Schmidt F.M., Le Maoult Y., Velay V.: Polymer Engineering and Science 2009, 49, 783. https://doi.org/10.1002/pen.21296

[35] Plucinsky P., Bhattacharya K.: Journal of the Mechanics and Physics of Solids 2017, 102, 125. https://doi.org/10.1016/j.jmps.2017.02.009

[36] Rozanski A., Galeski A., Debowska M.: Macromolecules 2011, 44, 20. https://doi.org/10.1021/ma1018523

[37] Fei G., Pu X., Zhuang T.et al.: Ultrasonics-Sonochemistry 2018, 40, 442. https://doi.org/10.1016/j.ultsonch.2017.07.036

[38] O’Leary K., Geil P.H.: Journal of Macromolecular Science Part B 1967, 1, 147. https://doi.org/10.1080/00222346708212743

[39] Karacan I., Benli H.: Journal of Applied Polymer Science 2011, 122, 3322. https://doi.org/10.1002/app.34440

[40] Song S.J., Feng J.C., Wu P.Y.: Journal of Polymer Science Polymer Physics 2011, 49, 1347. https://doi.org/10.1002/polb.22304
[41] Lee C.S., Caddell R.M., Atkins A.G.: Materials Science and Engineering 1975, 18, 213. https://doi.org/10.1016/0025-5416(75)90172-X

[42] Khan F., Hor A.M., Sundararajan P.R.: The Journal of Physical Chemistry B 2004, 108, 117. https://doi.org/10.1021/jp036306k

[43] Li G., Yao Y., Yang H. et al.: Advanced Functional Materials 2007, 17, 1636. https://doi.org/10.1002/adfm.200600624

[44] Cong H., Radosz M., Towler B.F., Shen Y.: Sep. Purif. Technol. 2007, 55, 281. https://doi.org/10.1016/j.seppur.2006.12.017

[45] Liu J., Guo T., Yang Y.: Journal of Applied Physics 2002, 91, 1595. https://doi.org/10.1063/1.1427435

[46] Fei G., Li G., Wu L., Xia H.: Soft Matter 2012, 8, 5123. https://doi.org/10.1039/C2SM07357A

[47] Fei G., Tuinea-Bobe C., Li D. et al.: RSC Advances 2013, 3, 24132. https://doi.org/10.1039/C3RA43640C

[48] Li D., Fei G., Xia H. et al.: Journal of Applied Polymer Science 2015, 132, 1. https://doi.org/10.1002/app.42416

[49] Ishinabe M., Yamashita Y., Tsutsumiuchi K. et al.: Transactions of the Materials Research Society of Japan 2017, 42, 107. https://doi.org/10.14723/tmrsj.42.107

[50] U.S. Pat. 5501590 (1996).

[51] U.S. Pat. 5352402 (1996).

[52] U.S. Pat. 5562960 (1996).

[53] Luo Y.M., Chevalier L.: AIP Conference Proceedings 2018, 1960, 120013-1. https://doi.org/10.1063/1.5034981

[54] Yan S., Menary G., Nixon J.: Mechanics of Materials 2017, 104, 93. https://doi.org/10.1016/j.mechmat.2016.10.006

[55] Vernerey F.J.: Journal of the Mechanics and Physics of Solids 2018, 115, 230. https://doi.org/10.1016/j.jmps.2018.02.018

[56] Nagarajappa C.: "Identification and validation of process parameters for stretch blow molding simulation", Queen's University Belfast, Belfast 2012.

[57] Krolikowski B.: Polimery 2007, 52, 752.

[58] Liga A., Montesanto S., Mannella G.A. et al.: Heat Mass Transfer 2016, 52, 1479. https://doi.org/10.1007/s00231-015-1652-x

[59] Cammalleri M., Pipitone E., Rubino T. et al.: Journal of Food Process Engineering 2015, 38, 445. https://doi.org/10.1111/jfpe.12175

[60] Roberts T.A., Cordier J.L., Gram L. et al.: "Microorganisms in Foods 6", Kluwer Academic/ Plenum Publishers, New York, Springer, New York 2005, pp. 643-715.

[61] Chen Y., Yu L.J., Rupasinghe V.: Journal of the Science of Food and Agriculture 2013, 93, 981. https://doi.org/10.1002/jsfa.5989

[62] Ramaswamy H.S., Chen C., Marcotte M.: "Processing 
Fruits: Science and Technology" (Ed. Barrett D.M.),

CRC Press, Boca Raton, FL, 2004, pp. 201-217.

[63] U.S. Pat. Appl. US 2010/0297313 A1.

[64] E-proPlast GmbH brochure, 2015.

http://www.e-proplast.eu/fileadmin/grp_redakteur/ images/downloads/PET-Hotfill_Fruit_juice-sauces_ en.pdf/ (accessed 1 January 2018).

[65] Shih W.H.: Polymer Engineering and Science 1994, 34, 1121.

https://doi.org/10.1002/pen.760341405
[66] Krones materials.

https://www.krones.com/en/products/machines/hotfilling-in-panel-free-pet-bottles.php.

[67] Nissei ASB materials.

http://www.nisseiasb.co.jp/en/products/meduim scale_hot_fill/.

[68] SIPA materials.

https://www.sipasolutions.com/en/magazine/sipaputs-the-cold-squeeze-on-hot-fill-drinks-bottles.

Received 12 XI 2019.

\section{W kolejnym zeszycie ukażą się m.in. następujące artykuły:}

G.A. Baig - Barwienie tkanin na bazie poli(kwasu mlekowego) - przegląd (j. ang.)

K. Bulanda, M. Oleksy, R. Oliwa, G. Budzik, Ł. Przeszłowski, A. Mazurkow - Biodegradowalne kompozyty polimerowe stosowane $\mathrm{w}$ technologii szybkiego prototypowania metodą osadzania stopionego polimeru (FDM) (j. ang.)

P. Wawrzyniak, W. Karaszewski - Przegląd literatury dotyczącej wpływu parametrów procesu rozdmuchiwania z jednoczesnym rozciąganiem z zastosowaniem gorącej formy rozdmuchowej na właściwości pojemników PET. Cz. II. (j. ang.)

S. Ravichandran, A.D. Raj, P.B. Visvanath, F. Mohammad, H.A. Al-Lohedan, S. Sagadevan - Wpływ rodzaju włókien na właściwości fizyczne laminatowych kompozytów polietylenu małej gęstości (j. ang.)

A. Adamus-Włodarczyk, E. Irzmańska - Ocena odporności chemicznej polimeru o właściwościach samonaprawiających do zastosowań w rękawicach ochronnych - studium przypadku

A. Nastaj - Optymalizacja procesu wytłaczania jednoślimakowego z dozowanym zasilaniem tworzyw polimerowych - badania symulacyjne 